\title{
Bacterial spatial distribution in the sediments of Gajah Mungkur Reservoir, Central Java, Indonesia
}

\author{
PENI PUJIASTUTI $^{1,2,}$, MASYKURI MASYKURI ${ }^{2}$, TOTOK GUNAWAN ${ }^{3}$, SUTARNO ${ }^{2}$ \\ ${ }^{1}$ Departement of Engineering, Universitas Setia Budi. Jl. Letjen. Sutoyo, Mojosongo, Surakarta 57127, Central Java, Indonesia. Tel: +62 813 2923 7707; \\ Fax: +62 271853 275, ’email: peni.usb@gmail.com \\ ${ }^{2}$ Department of Environmental Science, School of Graduates, Universitas Sebelas Maret. Jl. Ir. Sutami.36A, Surakarta 57126, Central Java, Indonesia \\ ${ }^{3}$ Departement of Geography, Universitas Gadjah Mada. Jl. Kaliurang, Sekip Utara, Bulaksumur, Sleman 55281, Yogyakarta, Indonesia
}

Manuscript received: 5 October 2015. Revision accepted: 28 October 2016.

\begin{abstract}
Pujiastuti P, Masykuri M, Gunawan T, Sutarno. 2016. Bacterial spatial distribution in the sediments of Gajah Mungkur Reservoir, Central Java, Indonesia. Biodiversitas 17: 907-914. The study aims to obtain the spatial dynamic pattern of bacterial sediment in the Gajah Mungkur Reservoir, Wonogiri, Central Java, Indonesia. This study supplied with colony morphology characterization, gram staining and biochemical test on the sediment samples that were obtained from eight contaminated zones. Furthermore, the spatial dynamic map based on the distance function using contour interpolation technique is processed using ArcView GIS 10 software. The research result shows that the distribution pattern of bacterial diversity is dynamic enough, identified by grampositive bacteria: Bacillus sp., Bacillus cereus, and Staphylococcus sp.; and gram-negative bacteria: Klebsiella, Escherichia coli, Aeromonas hydrophila, Aeromonas sobria, Aeromonas caviae, Aeromonas schubertii, Plesiomonas shigelloides, Acinetobacter sp., and Pseudomonas (Comamonas) acidovorans. Gram-positive anaerobic bacteria show similar distribution pattern in all samples, including Clostridium sphenoides, and Clostridium paraputrificums.
\end{abstract}

Keywords: Bacteria, distribution pattern, reservoir, sediment

\section{INTRODUCTION}

The waters of Gajah Mungkur Reservoir (GMR), Wonogiri, Central Java, Indonesia have degraded from year to year, identified by some findings, including: the occurrence of sedimentation (JICA 2007), which poses the life of GMR to a threat and the activities in the river basins Wiroko and Keduang, which have eutrophication in the GMR waters (Wiryanto et al. 2016). The fish feed residues stacking for years have decreased water acidity level and the availability of dissolved oxygen and increased $\mathrm{N}^{-\mathrm{NO}_{2}}$ and $\mathrm{N}-\mathrm{NH}_{3}$ contents. According to (Casali et al. 2010), farming activities produce sediment runoff, nitrate $(\mathrm{N}-$ $\left.\mathrm{NO}_{3}\right)$, and phosphate $\left(\mathrm{P}-\mathrm{PO}_{4}\right)$ which enter the stream, and therefore, this causes pollution in the water. The outlet of river basin continuously carries sediment runoff and dissolved nutrients $\left(\mathrm{N}-\mathrm{NO}_{3}, \mathrm{~N}-\mathrm{NH}_{3}, \mathrm{H}_{2} \mathrm{PO}_{4}\right.$ and $\left.\mathrm{K}\right)$ of $32 \%$ from the river basin, $18 \%$ from the forest, and $17 \%$ from the farming land (Duran Zuazo et al. 2012). 17.07-36.7\% of lands in the catchment area of GMR are utilized for farming activities (Bapeda 2012). The use of fertilizer causes a problem to the influx of a large number of Nitrogen to environment and farming activities that accelerate the Nitrogen transformation to the body of water (Xia et al. 2011). Fish-farming activities using floating fish cage and agricultural activities in catchment area have enriched nitrogen and phosphor in GMR waters (Pujiastuti et al. 2013). The high nutrient content makes water and sediment rich nutrients so it is a good habitat for microorganisms. There are a number of microorganisms populations in the sediment with high diversity (Bissett et al. 2007). In the 25-meter-depth sediment, bacteria population is found with the quantity of $4-90 \times 10^{6}$ cells $/ \mathrm{mL}$ (Nuchsin 2007). In the waters and sediment in Cirata, Saguling and Jatiluhur reservoirs of West Java, Indonesia, some pathogenic bacteria are found, including Bacillus badius, Bacillus brevis, Bacillus pumilus, and Pseudomonas (Jumiarni 2008). Some bacteria can cause the disease to the fish in Batam waters, such as Pseudomonas fluorescens, Pseudomonas alcaligenes, Enterobacter aerogenes, Citrobacter freundii, Aeromonas hydrophila, Aeromonas caviae, Aeromonas sobria, etc are found (Syarief 2013). From the samples of tropical seafood in India, including squid, shrimp, and fish, five species of Aeromonas are found, comprising Aeromonas hydrophila, Aeromonas enteropelogenes, Aeromonas caviae, Aeromonas punctata, and Aeromonas aquariorum (Joseph et al. 2013).

The Storet test based on water quality class 2, some point in the waters of GMR has experienced pollution at the moderate to severe category. At every turn of the dry season to the rainy, death of fish en massive at GMR. In floating net area, an amount of dead fish, average 70 tons per day. Bacteria Streptococcus sp. caused the death of Oreochromis niloticus in GMR The existence of pathogenic bacteria in water reservoirs, can cause a decrease in dissolved oxygen and causing infections in fish. GMR Oreochromis niloticus contain Streptococcus agalactiae and Streptococcus pneumonia, with pathogenecity of up to $100 \%$. Pathogenic bacteria in the waters do not only cause disease to some living creatures in the Lake, but also have 
an important role in the natural purification process, for instance Bacillus sp. (Azlina and Norazila 2013). Comamonas kerstersii KSM7 (Swamy et al. 2014), Staphylococcus aureus (Nurhayati et al. 2012), Escherichia coli, and Pseudomonas sp. (Badjoeri and Widianto 2008); they can produce protease enzyme which makes a contribution in hydrolyzing or degrading organic pollutants containing protein to be a simpler substance. These research aims at obtaining spatial dynamic pattern of sediment bacteria in GMR, as an environmental information system, functioning to identify the local biodiversity which has an important role in natural purification of the pollutant in GMR waters. Several studies have been conducted to determine the status of water quality in the zone of floating net and outlet GMR, on the parameters of physics, chemistry, and biology. The Biological parameters that have been investigated are Escherichia coli and total coliform. This study reinforce some previous research, through the study of the distribution of pathogenic bacteria in the sediment at 8 points GMR polluted zone.

\section{MATERIALS AND METHODS}

\section{Study area and sample collection}

This research material is the sediment of Gajah Mungkur Reservoir (GMR), Wonogiri, Central Java, Indonesia in the contaminated zone taken at the peak of the dry season in 2014 at 5-7 meters depth. The sampling point was taken in Station 1 in traditional floating fish cage area (S 07 52'01.1', E 110 54'13.6'), Station 2 in modern floating fish cage (S 07 $52^{\prime} 12.1^{\prime \prime}$, E $\left.110^{\circ} 54^{\prime} 17.9^{\prime \prime}\right)$, Station 3 in tourism area (S 07 $51^{\prime} 30.50^{\prime \prime}$, E 110 $54^{\circ} 47.06^{\prime \prime}$ ), Station 4 in reservoir center (S 07 54'1.19', E $\left.110^{\circ} 53^{\prime} 40.73^{\prime \prime}\right)$, Station 5 in free area (S 07 $54^{\circ} 09.0^{\prime}$ ', E $110^{\circ} 53^{\prime} 36.9^{\prime \prime}$ ), Station 6 in Wuryantoro estuary (S $07^{\circ} 54^{\prime} 39.3$ ', E $\left.110^{\circ} 52^{\prime} 38.9^{\prime \prime}\right)$, Station 7 in Alang estuary (S 07'54'36.0', E 110 53'44.4',), Station 8 in Wiroko estuary (S 07 53'48.6', E 110 54'24.0'”) (Figure 1).

The sampling tools employed were Ekman grab sampler and GPS. The bacteria were grown on Nutrient Agar with Cappuccino and Sherman method (2005), and then colony morphology characterization test, gram staining, and biochemical test were conducted. The obtained data were compared with standard description provided in Helt et al. (1994). The spatial dynamic mapping of the diversity of sediment bacteria was carried out using ArcView GIS 10 software (ESRI, Redlands, CA, USA).

\section{Instrument, chemical and microbiological media}

Media to growth all bacteria in sediments, used universal media Agar Nutrient. Special instrument and chemically anaerobic, used (i) Anaerobic jar oxoid, E Merck, BBL. (ii) Gas generating kit and anaerobic indicator. (iii) Catalisator, (iv) Anaerocult $\mathrm{A}$ and Anaerotes. (v) Metronidazole disc $5 \mathrm{mcg}$. Media to growth anaerobic used Thioglycolate broth. Media culture bacteria aerobic used Blood agar plate and MacConkey agar plate.

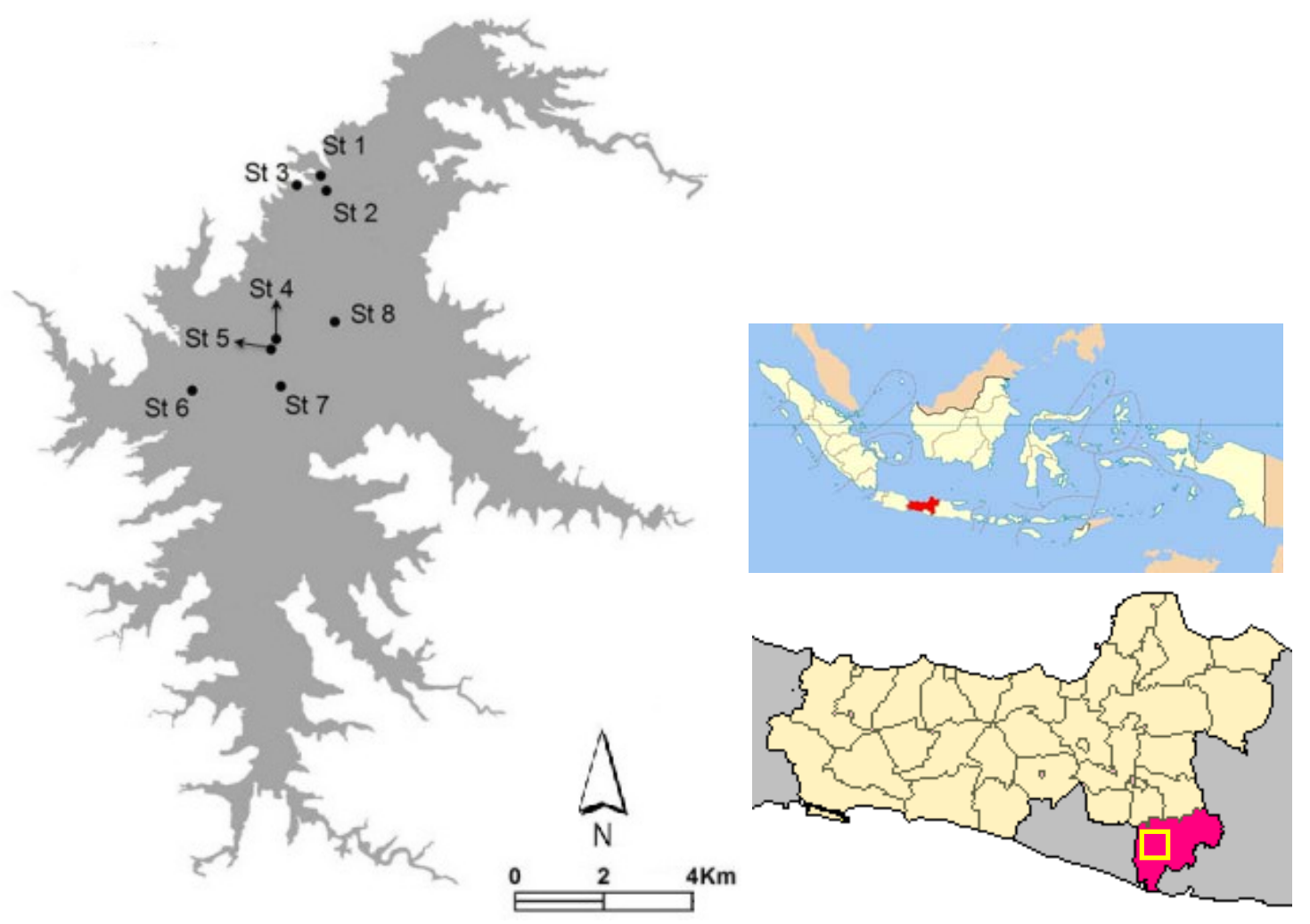

Figure 1. The map of sediments station sampling in Gajah Mungkur Reservoir, Wonogiri, Central Java, Indonesia 


\section{Isolation of reservoir bacteria sediment}

Bacterial culture isolation: (i) Aseptically inoculate samples onto Nutrient Agar plates labeled with pertinent case history information, (ii) Incubate aerobically for 24-48 hours at $20-24^{\circ} \mathrm{C}$. If no growth occurs at 24 and 48 hours. If no growth occurs after 96 hours, samples are discarded. (iii) When growth does occur on field collection tubes or plates, use a sterile loop or needle to select a single colony to subculture onto fresh Nutrient Agar. If colonies are not well isolated, the plate will have to be re-inoculated on Nutrient Agar and thoroughly struck over the entire plate surface to achieve isolation of bacteria. (iii) Incubate at 20$24^{\circ} \mathrm{C}$ for 24 hours to allow bacterial growth; all test should be performed on 24-48 hour cultures. (iv) Inoculate biochemical tubes. (v) Treat all bacterial cultures as potential human pathogens.

\section{Identification of bacterial strain}

Gram staining, it is a differential staining technique used to characterize bacteria as Gram-positive and Gramnegative. Steps of Gram staining of bacteria: (i) Fixation of sediment smear, (ii) Flood the fixed smear sediment with crystal violet solution, and allow to remain for 1 minute, and then rinse of the crystal violet with distilled water, (iii) Flood the slide with iodine solution, allow to remain for 1 minute, and then rinse off the iodine solution with distilled water, (iv) Flood the slide with decolorizer for 30 second, after that rinse off the decolorizer with distilled water, (v) Flood the slide with safranin, allow to remain for 30 second, after that rinse off the safranin with distilled water. (vi) Dry the slide, and see the slide for bacterial organism on microscope binocular under 100x objective. Observe several fields on slide for bacteria organisms. Describe the gram reaction of any organisms seen. Gram-positive bacteria stain deep violet, and gram-negative bacteria stain pink to red.

Biochemical test: Indole, catalase, oxydase test, coagulase test, $\mathrm{H}_{2} \mathrm{~S}$ test, citrat test, etc. Biochemical activities were determined according to the recommended scheme of Helt et al. (1994).

\section{RESULTS AND DISCUSSION}

\section{Identification of aerobic and anaerobic bacteria in samples of GMR sediment}

Indole test is performed to help differentiate species of the family Enterobacteriaceae. Bacteria that possess the enzyme tryptophanase are capable of hydrolyzing and deaminating tryptophan with the production of indole, pyruvic acid and ammonia. Interpretation Indole test is development of bring red color at the interface of the reagent and the broth within seconds after adding the reagent is indicative of presence of Indole and positive test. Indole positive: E. coli and Proteus vulgaris. Indole negative are Salmonella sp., Klebsiella sp., Enterobacter aerogenes. The result biochemical tests are shown in Table 1. The results of study of colony characteristics and Gram stain are presented in Tables 2 and 3.

\section{Discussion}

On the basis of the results of laboratory analysis on water samples of estuaries of the sub-river basin, floating fish cage area, and the central area of the reservoir, and later the test of water quality class 2 using Storet method, some sampling points reveal moderately to highly polluted water. Reservoir water system has the natural capability to carry out self-purification process. However, in case that the presence of organic compounds exceeds the capability of self-purification, accumulation of organic compounds and formation of toxic materials in water are uncontrollable, and hence, result in the decrease in water quality (Badjoeri and Widianto 2008). Aquatic pathogenic bacteria contribute to aquatic self-purification. As the purification is ongoing, biotransformation in which enzymes produced by micro-organisms modify toxic pollutants by changing their chemical structure occurs. This biotransformation leads to bio-gradation in which the toxic pollutants are degraded, their structures become in complex and finally transform to harmless and non-toxic metabolites (BPPT 2014).

Table 1. The results of biochemical tests in the sediment of Gajah Mungkur Reservoir, Wonogiri, Central Java, Indonesia

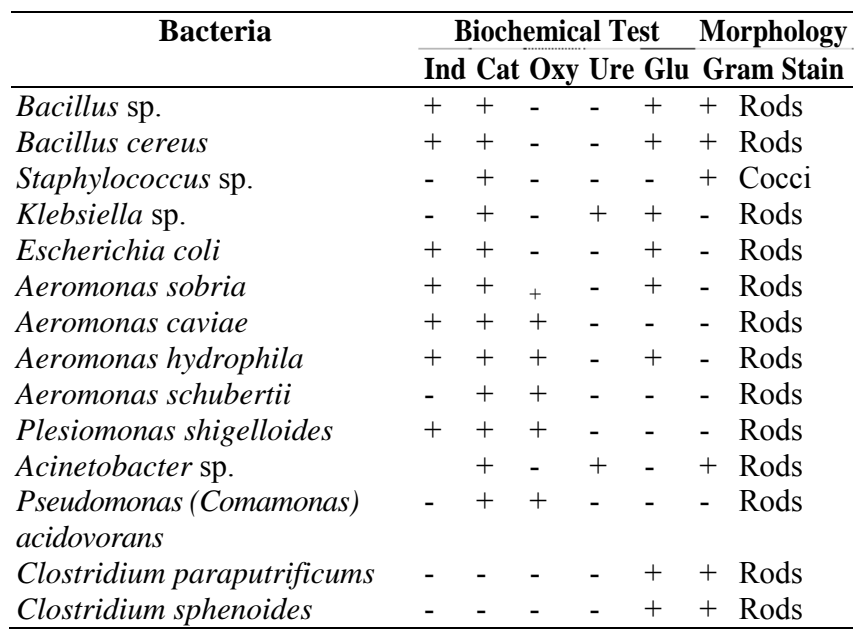

Note: Test Ind: indole, Cat: catalase, Oxy: oxydase, Ure: urease, Coa: coagulase, Glu: glucose

Table 3. Anaerobic bacteria in the sediment samples of Gajah Mungkur Reservoir, Wonogiri, Central Java, Indonesia

\begin{tabular}{lll}
\hline $\begin{array}{l}\text { Sampling } \\
\text { station }\end{array}$ & \multicolumn{1}{c}{ Anaerobic bacteria } \\
\cline { 2 - 3 } St. 1 & \multicolumn{1}{c}{ Gram +} & Gram- \\
St. 2 & $\begin{array}{l}\text { Clostridium paraputrificums } \\
\text { Clostridium sphenoides }\end{array}$ & $\begin{array}{c}\text { Not found } \\
\text { Not found }\end{array}$ \\
St. 3 & $\begin{array}{l}\text { Clostridium paraputrificums } \\
\text { Clostridium sphenoides }\end{array}$ & Not found \\
St. 4 & $\begin{array}{l}\text { Clostridium paraputrificums } \\
\text { Clostridium sphenoides }\end{array}$ & Not found \\
St. 5 & $\begin{array}{l}\text { Clostridium paraputrificums } \\
\text { Clostridium sphenoides }\end{array}$ \\
St. 6 & $\begin{array}{l}\text { Clostridium sphenoides } \\
\text { St. } 7\end{array}$ & Clostridium paraputrificums \\
St. 8 & Clostridium sphenoides & Not found \\
& & Not found \\
\hline
\end{tabular}


Table 2. Aerobic bacteria in the sediment samples of Gajah Mungkur Reservoir, Wonogiri, Central Java, Indonesia

\begin{tabular}{|c|c|c|c|c|}
\hline \multirow{2}{*}{$\begin{array}{c}\text { Sampling } \\
\text { station }\end{array}$} & \multirow{2}{*}{ Figures of bacteria } & \multirow{2}{*}{ ALT cfu/mL) } & \multicolumn{2}{|c|}{ Aerobic } \\
\hline & & & GRAM + & GRAM- \\
\hline St. 1 & & $5.01 \times 10^{5}$ & Bacillus sp. & $\begin{array}{l}\text { Klebsiella sp. } \\
\text { E. coli } \\
\text { Aeromonas sobria } \\
\text { Aeromonas caviae }\end{array}$ \\
\hline St. 2 & & $3.50 \times 10^{5}$ & $\begin{array}{l}\text { Bacillus sp. } \\
\text { Bacillus cereus } \\
\text { Staphylococcus sp. }\end{array}$ & $\begin{array}{l}\text { Klebsiella sp. } \\
\text { E. coli } \\
\text { Aeromonas hydrophila } \\
\text { Plesiomonas shigelloides } \\
\text { Acinetobacter sp. }\end{array}$ \\
\hline St. 3 & & $1.16 \times 10^{4}$ & Bacillus sp. & $\begin{array}{l}\text { E. coli } \\
\text { Aeromonas schubertii } \\
\text { Pseudomonas } \\
\text { (Comamonas) } \\
\text { acidovorans }\end{array}$ \\
\hline St. 4 & & $4.06 \times 10^{5}$ & Bacillus sp. & $\begin{array}{l}\text { Klebsiella sp. } \\
\text { E. coli } \\
\text { Aeromonas sobria }\end{array}$ \\
\hline St. 5 & & $4 ., 18 \times 10^{5}$ & $\begin{array}{l}\text { Bacillus sp. } \\
\text { Bacillus cereus }\end{array}$ & $\begin{array}{l}\text { E. coli } \\
\text { Aeromonas caviae }\end{array}$ \\
\hline
\end{tabular}


St. 6

St. 7

St. 8

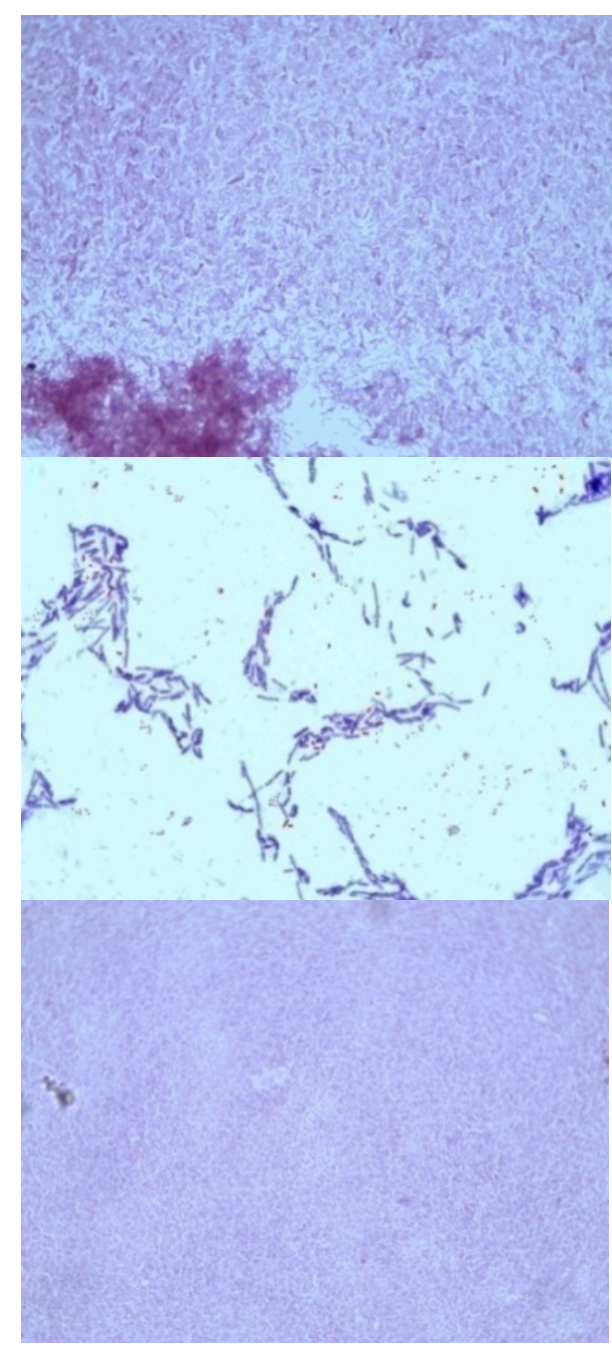

$4.67 \times 10^{5} \quad$ Bacillus sp.

$1.12 \times 10^{5}$

Bacillus sp.

Staphylococcus sp.

Klebsiella sp.

E. coli

Aeromonas sobria

$6.35 \times 10^{5}$

Bacillus sp.

Bacillus cereus
Klebsiella sp.

E. coli

Aeromonas sobria
The distribution of bacteria in the sediment of GMR

Sediment microorganism plays a crucial role in a variety of biogeochemical processes in freshwater ecosystems (Liu et al. 2014). Bacteria commonly reproduce well in reservoir sediment since it provides nutrition for microorganisms. Escherichia coli, Citrobacter, Klebsiella, and Enterobacter are defined as all types of aerobic, facultative anaerobic and rod-shaped bacteria which are able to ferment lactose and produce gasses in 48 hours with the temperature of $35^{\circ} \mathrm{C}$ (Marganof 2007). Distribution of both aerobic and anaerobic bacteria found in GMR can be seen in the following figure 2. Observation result of sediment taken from polluted zone shows that both aerobic and anaerobic bacteria have been identified. This is shown in Table 2 and Table 3.

\section{Bacillus}

Bacillus species, gram-positive and rod-shaped bacteria, can grow in aerobic environment. They are found separately in whole sampling areas of Alang estuary, Wuryantoro estuary, floating fish cage and the central of GMR. They play a role in the process of nitrification and denitrification, and they function as nitrogen binder, $\mathrm{Se}$ oxidizer, and Mn reducer/oxidizer. Moreover, they are able to dissolve carbonate and phosphates, decrease substrate $\mathrm{pH}$ due to acidic properties which are produced, mineralize complex organic compounds such as polysaccharides, protein, and cellulose. Alang and Wuryantoro Estuaries have $0,01 \mathrm{mg} / \mathrm{L}$ of $\mathrm{N}-\mathrm{NO}_{3}, 0,013 \mathrm{mg} / \mathrm{L}$ of $\mathrm{N}-\mathrm{NH}_{3}$ and $0,0015 \mathrm{mg} / \mathrm{L}$ of $\mathrm{N}_{-} \mathrm{NO}_{2}$, fulfilling the standard of quality. The small amount of nitrogen exists as a result of the role of Bacillus sp.

\section{Aeromonas}

Aeromonas species are gram-negative bacteria, potential pathogenic to the environment, and they produce cytotoxin (Balaji et al. 2004). They can reproduce in highly-polluted fresh water. Aeromonas hydrophila, Aeromonas sobria, Aeromonas caviae and Aeromonas schubertii are Aeromonas species found in GMR sediment. Their distribution is figured 3 out below. Aeromonas sobria bacteria are found in the sediment of Alang estuary, that of floating fish cage and spread to that of a center of the reservoir. Aeromonas hydrophila bacteria are identified in the sediment of floating fish cage and are not found in other sampling points. Camus et al. (1998) state that 
Aeromonas hydrophila, Aeromonas sobria and Aeromonas caviae are associated with fish. The latter appear in the sediments of floating fish cage and free zone, while Aeromonas schubertii bacteria are only found in the sediment of tourism water area. The former have more vicious characteristic than the middle do (Cipriano 2001). As pathogenic bacteria, Aeromonas may bring about MAS (Motile Aeromonas septicemia) which is also known as red sore disease, hemorrhagic septicemia, and ulcer disease (Samcookiyaei et al. 2012). Angka (2005) highlights that bacterial infection of Aeromonas hydrophila causes fish to suffer from this disease. It attacks all life cycle stages of fish specifically larval and fry stages (Camus et al. 1998). In addition, it can infect common carp (Cyprinus carpio) and walking catfish (Clarias batrachus), while Aeromonas caviae may attack goldfish (Carassius auratus) Minaka et al. (2012). Aeromonas veronii bv. sobria were highly pathogenic to Oreochromis niloticus (Eissa et al. 2015). Aeromonas veronii Av27, highly resistant to tributyltin (TBT $3 \mathrm{mM}$ ) uses this compound as carbon source and degrades it to less toxic compounds (Cruz et al. 2007).

\section{Escherichia coli}

Escherichia coli bacteria are found in sediments of all sampling points of a polluted zone in GMR. Their presence serves as an indicator of water pollution due to fecal matter. Determination of fecal coliform is used as an indicator of pollution since its number of colonies must be positively correlated with the presence of pathogenic bacteria. It is possible that other enteric pathogens, along with E. coli, are also found in the zone. E. coli bacteria enter GMR through river flow of all sub-river basins and spread along waters and sediments of the reservoir. The number of E. coli in GMR reservoir, in Alang estuary, in Wuryantoro estuary, in floating fish cage and in the center of the reservoir ranges between $780.10^{2} / 100 \mathrm{~mL}$ $33.10^{1} / 100 \mathrm{~mL}, 12.10^{0}-23.10^{0} / 100 \mathrm{~mL}, 94.10^{1}-140.10^{1} / 100$ $\mathrm{mL}, 23.10^{0}-540.10^{0} / 100 \mathrm{~mL}$, and $<1,8.10^{\circ}-19.10^{0} / 100 \mathrm{~mL}$ respectively. Pathogenic bacteria, found along with $E$. coli, appear mostly in fish cage owned by Aquafarm Company, in the sediment of Alang estuary and in the sediment of the free zone with a total number of 8 bacteria, 6 bacteria, and 4 bacteria respectively.

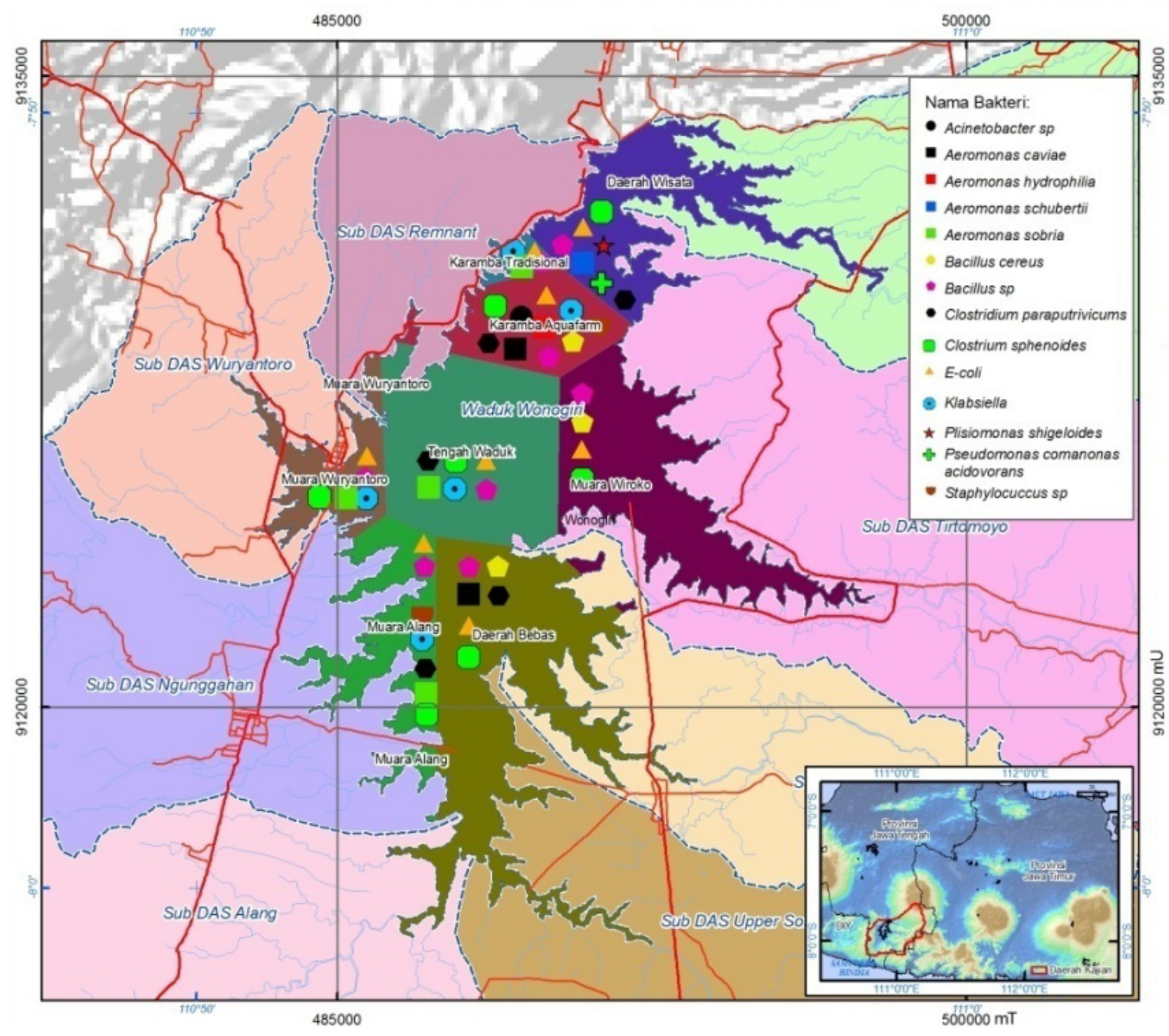

Figure 2. Distribution of aerobic and anaerobic bacteria in polluted zone of Gajah Mungkur Reservoir, Wonogiri, Central Java, Indonesia 


\section{Klebsiella}

Klebsiella sp. is gram-negative, rod-shaped, and facultative anaerobic bacteria which are unable to produce spores. They can grow at temperature of $12-43^{\circ} \mathrm{C}$. Klebsiella is pathogenic, which means that they are able to ferment carbohydrate to form acid and gas, and hydrolyze urea. They belong to the group of coliform bacteria. The existence of Klebsiella sp. is identified in the sediments of Alang estuary, Wuryantoro estuary, and floating fish cage areas. Klebsiella $s p$ are also found spreading into the central area of GMR. The existence of the bacteria has a close relation with the organic pollutant content, like carbohydrate, which is measured with $\mathrm{BOD}_{5}$ and $\mathrm{COD}$ parameters. In dry season, the water area of Alang estuary has the $\mathrm{BOD}_{5}$ level of $1.2 \mathrm{mg} / \mathrm{L}$ below class 2 water quality standard of $3.0 \mathrm{mg} / \mathrm{L}$, and COD level of $19.6 \mathrm{mg} / \mathrm{L}$ below class 2 water quality standard of $25 \mathrm{mg} / \mathrm{L}$. Wuryantoro water area has the $\mathrm{BOD}_{5}$ level of $2.3 \mathrm{mg} / \mathrm{L}$ and COD level of $19.6 \mathrm{mg} / \mathrm{L}$. Floating fish cage area has the $\mathrm{BOD}_{5}$ level of $2.6 \mathrm{mg} / \mathrm{L}$ and COD level of $15.3 \mathrm{mg} / \mathrm{L}$. Meanwhile, the central area of the reservoir has the $\mathrm{BOD}_{5}$ level of $2.5 \mathrm{mg} / \mathrm{L}$ and COD level of $25.5 \mathrm{mg} / \mathrm{L}$. The low level of $\mathrm{BOD}_{5}$ and COD scores are predicted to have a close relation with the existence of Klebsiella $s p$ in the sediment, which has an ability to degrade organic pollutant in the form of carbohydrate into simpler molecule and gas.

\section{Pseudomonas (Comamonas) acidovorans}

Pseudomonas (Comamonas) acidovorans are only found in the sediment of tourism area of GMR. These bacteria are gram-negative. They play important roles in degrading complex organic pollutants and reducing chromium contents in contaminated water (Rudakiya and Parwar 2014). These species do not infect fish. There are three types of Pseudomonas which can infect fish in reservoir, including Pseudomonas anguilliseptica, Pseudomonas chlororaphis, and Pseudomonas fluorescens. The $\mathrm{BOD}_{5}$ and COD levels in tourism water area are 2.8 $\mathrm{mg} / \mathrm{L}$ and $21.6 \mathrm{mg} / \mathrm{L}$ below the water quality standard level two. The government regulation of the Republic of Indonesia $82 / 2001$ regarding water quality management is estimated to have a relation with the existence of bacteria and their abilities, Pseudomonas (Comamonas) acidovorans, to degrade complex organic pollutants.

\section{Acinetobacter sp.}

Acinetobacter sp. are anaerobic and gram-negative bacteria. Growth on MacConkey agar, the biochemical characteristics are catalase positive, oxydase negative and glucose positive (Constantiniu el al. 2004). They need oxygen as the terminal electron in metabolism. They can grow in $20-30^{\circ} \mathrm{C}$. They are able to use hydrocarbon chain as nutrient source, and therefore, they can remediate the oil content in water. In Gajah Mungkur Reservoir, Acinetobacter sp. can only be found in the sediment of floating fish cage. Oil, carbohydrate, and protein are organic pollutants, and therefore, they can be measured with $\mathrm{BOD}_{5}$ and COD. The existence of these bacteria in floating fish cage sediment can help reduce the number of organic pollutants.

\section{Clostridium sphenoides and Clostridium paraputrificums}

Clostridium sphenoides and C. paraputrificums are gram positive rods, which may possess a single endospore. There are anaerobic bacteria. Clostridium sphenoides can be isolated in almost all of sediments of contaminated zones in GMR, except for traditional floating fish cage sediments. Meanwhile, Clostridium paraputrificums can be isolated in the sediments of Alang estuary, tourism area, and free and central area of GMR. Those types of bacteria are non-pathogenic to water biota. Clostridium sphenoides and Clostridium paraputrificums give variable indole test result usually negative (PHE 2015). This bacteria can't produce indole from the degradation of the amino acid tryptophan.

In conclusion, from sediment in polluted zone 8 , the water area of GMR, which is taken as the sample in dry season, 14 bacteria are identified and isolated. The anaerobic bacteria found to consist of 12 genus/species, including gram-positive bacteria such as Bacillus sp., Bacillus cereus, and Staphylococcus sp., and gram-negative bacteria such as Klebsiella, E. coli, Aeromonas hydrophila, Aeromonas sobria, Aeromonas caviae, Aeromonas schubertii, Plesiomonas shigelloides, Acinetobacter sp., and Pseudomonas (Comamonas) acidovorans. Grampositive anaerobic bacteria have the same distribution patterns at every sampling point. Those bacteria are Clostridium sphenoides, Clostridium paraputrificums. Meanwhile, there are no gram-negative anaerobic bacteria found. The distribution of bacteria in the sediment of GMR is quite dynamic. The most types of bacteria, totally 9 bacteria, are found in the sediment of floating fish cage. $E$. coli, Bacillus sp. and Clostridium sphenoides dominate in all sediments in contaminated zones used as samples.

\section{ACKNOWLEDGEMENTS}

The researchers would like to express their deep gratitude to the Ministry of Research, Technology, and Higher Education for the financial support of doctoral research grant; Setia Budi Education Foundation for the doctoral program scholarship; promoter and co-promoter; sampling teams; and CGS for the help to finish the spatial distribution mapping.

\section{REFERENCES}

Angka. 2005. Study of Motile Aeromonas septicemia (MAS) in Walking Calfish (Clarias sp.), Pathology, Preventive and Curative using Phytopharmaca [Dissertation]. Instutut Pertanian Bogor, Bogor.

Azlina IN, Norazila Y. 2013. Thermostable Alkaline Serine Protease from Thermophilic Bacillus Species. Int Res J Biol Sci;2 (2): 29-33.

Badjoeri M, Widianto T. 2008. The use of nitrification bacteria for bioremidiation and its influence on the concentration of ammonia and nitrite in shrimp pond. J Oseanology and Limnology Indonesia. 34: 261-278. 
Balaji V, Jesudason MV, Sridharan G. 2004. Cytotoxin testing of environmental Aeromonas spp. in Vero cell culture. Indian J Med Res. 119: 186-9.

Bapeda. 2012. Collaboration Program on Management of Bengawan Solo River Basin Upstream. Govt of Wonogiri District, Wonogiri. [Indonesian]

Bissett A, Burke C, Cook PL, Bowman JP. 2007. Bacterial community shifts in organically perturbed sediments. Environ Microbiol. 9 (1): 46-60.

BPPT. 2014. Bioremediation to Reduce Environment Pollutants. BPPT, Jakarta. [Indonesian]

Camus AC, Durborow RM, Hemstreet WG, Thune RL, Hawke JP. 1998 Aeromonas Bacterial Infections, Motile Aeromonas septicemia. SRAC Publication No. 478.

Cappuccino JG, Sherman N. 2005. Microbiology a Laboratory Manual, 7 th ed. Benjamin/Cummings, San Francisco.

Casali J, Giménez R, Díez J, Álvarez-Mozos J, de Lersundi JDV, Goñi M, 2010. Sediment production and water quality of watersheds with contrasting land use in Navarre (Spain). Agric Water Manag 97 (10): 1683-1694.

Cipriano CR. 2001. Aeromonas hydrophila and motile Aeromonas septicemias of fish. Fish Dis Leafl 68. Fish and Wildlife Service Division of Fishery Research, Washington, D.C.

Constantiniu S, Romaniuc A, Iancu LS, Filimon R, Tarasi I. 2004 Cultural and biochemical characteristics of Acinetobacter spp. strains isolated from hospital units. J Prevent Med 12 (3-4): 35-42.

Cruz A, Caetano T, Suzuki S, Mendo S. 2007. Aeromonas veronii, a tributyltin (TBT)-degrading bacterium isolated from estuarine environment, Ria de Aveiro in Portugal. Mar Environ Res 64: 639650 .

Durán Zuazo VH, Francia Martínez JR, García Tejero I, Rodríguez Pleguezuelo CR, Raya AM, Cuadros Tavira S. 2012. Runoff and sediment yield from a small watershed in southeastern Spain (Lanjarón): implications for water quality. Hydrol Sci J 57 (8): 16101625 .

Eissa IAM, El-lamei M, Sherif M, Desuky E, Zaki M, Bakry M. 2015. Aeromonas veronii sobria a causative agent of mass mortalities in cultured nile tilapia in-Sharkia governorate, Egypt. Life Sci J 12 (5). http: //www.lifesciencesite.com.

Helt JG, Krieg NR, Sneath PHA, Staley JT, Williams ST. 1994, Bergey's Manual of Determinative Bacteriology, 9th ed. William \& Wilkins, Baltimore, Maryland USA.

JICA. 2007. The Study on Countermeasures for Sedimentation in the Wonogiri Multipurpose Dam Reservoir in Republic of Indonesia. Japan International Cooperation Agency, Tokyo.

Joseph AV, Sasidharan RS, Nair HP, Bhat SG, Joseph AV, Sasidharan RS. 2013. Occurrence of potential pathogenic Aeromonas species in tropical seafood, aquafarms and mangroves off Cochin coast in South India. Vet World 6 (6). DOI: 10.1.1.435.131

Jumiarni D. 2008. Isolation and Identification of Bacteria Reservoir Sediments. Faculty of Teacher Training and Education, Universitas Bengkulu, Bengkulu. [Indonesian]

Liu Y, Zhang JX, Zhao L, Zhang XL, Xie SG. 2014. Spatial distribution of bacterial communities in high-altitude freshwater wetland sediment. Limnology 15: 249. DOI: 10.1007/s10201-014-0429-0.

Marganof. 2007. Model Pollution Control Water bodies in Lake Maninjau, West Sumatra. School of Graduates, Institut Pertanian Bogor, Bogor. [Indonesian]

Minaka A, Sarjito, Hastuti S. 2012. Identification of agents causes and blood profile gouramy which esophageal disease bacteria. J Aquacult Manag Technol 1 (1): 249-263. [Indonesian]

Nuchsin R. 2007. Vertical distribution of bacteria population in relation to chlorophyll-a in East Kalimantan waters. Makara Sains 11 (1): 10-15. [Indonesian]

Nurhayati T, Fikri M, Desniar D. 2012. Protease inhibitor activity of extracts soft coral from panggang island of a seribu islands water. Indonesian marine science, J Mar Sci 15 (2): 59-65.

PHE [Public Health England]. 2015. Identification of Clostridium species. UK Standard for Microbiology Investigations. ID 8 Issue 4.1. Standards Unit, Microbiology Services, PHE, London.

Pujiastuti P, Ismail B, Pranoto P. 2013. Water quality and pollution load of Gajah Mungkur Reservoir. Jurnal Ekosains 5 (1): 59-75. [Indonesian]

Rudakiya D, Pawar K. 2014. Bioremediation potential of Comamonas acidovorans MTCC 3364 for the removal of sulfonated di-azo dye Reactive Black B. Intl J Agric Environ Biotechnol 7: 525-535.

Samcookiyaei A., Alsharnasab M., Razavilar V., Motalebi A., Kakoolaki S., Asadpor Y., Yahyazade M.Y., Nekuie Fard A. 2012. Experimentally pathogenesis of Aeromonas hydrophila in freshwater Crayfish (Astacus leptodactylus) in Iran. Iranian J Fish Sci 11 (3): 644-656.

Swamy MK, Sudipta KM, Rohit KC, Purushotham B, Rudramurthy GR. 2014. Isolation, screening and optimization of factors effecting protease production from Comomonas kerstersii KSM7. Intl J PharmTech Res 6 (2): 858-867.

Syarief A. 2013. Monitoring reports HPI/HPIK in 2013. Fish Quarantine Station, Quality Control And Safety of Fishery Class I, Batam.

Wiryanto. 2016. Spatial and temporal description of water pollution status of Gadjah Mungkur Reservoir Wonogiri, Central Java, Indonesia. Biodiversitas 17: 888-893.

Xia Y, Huang LG, Xu LG. 2011. Characteristics of diffuse source N pollution in Lean River catchment. Procedia Environ Sci 10: 24372443 